\title{
Amaranthus powellii (Amaranthaceae), a new addition for the flora of India and a preliminary list of the Indian Amaranthus species
}

\author{
Sindhu Arya ${ }^{1}$ (D) Duilio lamonico ${ }^{2, *}$ (1) \& Venugopalan Nair Saradamma Anil \\ Kumar $^{3}$ (i)
}

Key words: Alien species, Amaranthus species list, Asia, new record.

Ključne besede: tujerodne vrste, seznam vrst rodu Amaranthus, Azija, nove najdbe.

\begin{abstract}
Three populations of Amaranthus powellii were discovered in Kerala region (SE-India), representing the first record of this species for the national flora. A morphological description based on the Indian plants, as well as ecological data are given. A preliminary list of all the Amaranthus species occurring in India, which was never published during the last 136 years, is also provided.

Izvleček

V regiji Kerala (JI-Indija) smo odkrili tri populacije vrste Amaranthus powellii, ki predstavljajo prvo najdbo te vrste v flori Indije. Na osnovi primerkov iz Indije smo podali morfološki opis in ekološke podatke. Sestavili smo tudi seznam vseh vrst rodu Amaranthus z območja Indije, ki je ponovno objavljen po 136 letih.
\end{abstract}

1 Department of Botany, Research centre University of Kerala, University College, Thiruvananthapuram, 695034-Kerala, India.

2 Department of Botany, University of Pisa, Via Luca Ghini 13, 56126-Pisa, Italy.

3 Department of Botany, Government College, Vidhya Nagar, Kasaragod, 671123-Kerala, India.

* Corresponding author. E-Mail: d.iamonico@yahoo.it 


\section{Introduction}

The genus Amaranthus L. (Amaranthaceae Juss.) includes 65-70 species of which approximately half are native to the Americas (see Mosyakin \& Robertson 1996, Iamonico 2015a). Some species are used as ornamentals, food or medicine and are able to escape from cultivation, negatively impacting the agricultural systems and/or the natural vegetation (see Iamonico 2010, 2015a, Das 2016).

Amaranthus is a taxonomically critical genus, due to its high phenotypic variability which has resulted in the current nomenclatural confusion and misapplication of several names (see e.g., Costea et al. 2001, Bayón 2015, Iamonico 2016a, 2016b, 2016c, 2020a, 2020b, 2020c Iamonico \& Palmer 2020).

As part of an ongoing investigation on the Indian species of Amaranthus (Iamonico \& Das 2014, Arya et al. 2019, Sindhu et al. 2020), we found some populations of Amaranthus powellii S. Watson, a species never recorded for the national flora. Morphological notes, as well as ecological data are presented here. A preliminary list of all the Amaranthus species occurring in India, which were never published since 136 years, is also provided.

\section{Materials and methods}

The research is based on field surveys [collected specimens are deposited at CALI, HFLA, and TBGT], analysis of relevant literature, and examination of specimens preserved at AO, APP, FI, HFLA, G, GH, K, KFRI, MH, NY, RO, and TSB (herbarium codes follow Thiers 2021 [continuously updated]).

The description of the species is based on the plants observed in field.

\section{Results and discussion}

\section{First record for Indian flora}

Amaranthus powellii, a species originally described by Watson (1875: 347) from Arizona, is native to North America and Mexico (see e.g., Mosyakin \& Robertson 2003), whereas it was considered as alien in North and Central Africa [Morocco and Algeria (see Iamonico 2015b, SANBI 2012), Ethiopia, Uganda, and Tanzania (see Costea et al. 2001)], Asia [Pakistan (see Costea et al. 2001), and Korea (Park et al. 2014)], Australia (Palmer 2009), and Europe (Iamonico 2015b).

Three populations of Amaranthus powellii were found in South India, Kerala State, Kasaragod District, in Chengala suburb (localities Naimarmoola and $4^{\text {th }}$ Miles) and Mulleria town (Figure 1), at elevation 54-173 m a.s.l.

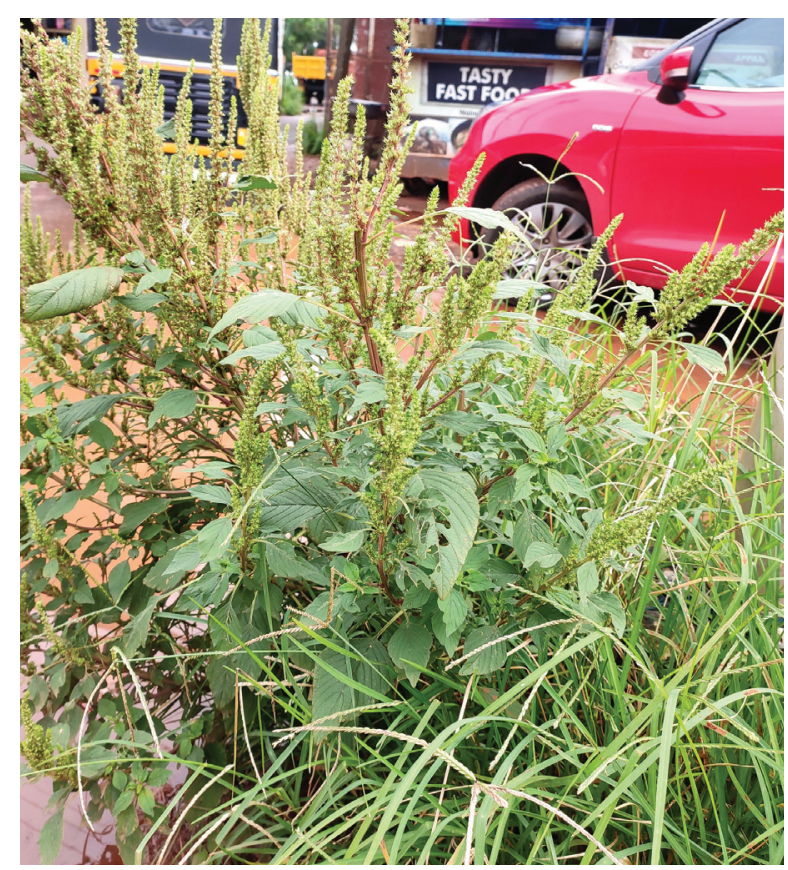

Figure 1: Amaranthus powellii in India (photos by A. Sindhu). Slika 1: Amaranthus powellii v Indiji (fotografije A. Sindhu).

The first observation of Amaranthus powellii was in 2018 and the populations found still occur in the above mentioned sites. A total of 27-35 individuals were counted in these sites occupying an area of about $3 \mathrm{~m}^{2}$ per site. We observed the flowering and fruiting times from June to February. On the basis of literature (see the above mentioned citations and the paragraph 3.2 below), these populations represent the first record of this species for the Flora of India (see also POWO 2020-onward).

Since the recent observation (2018) and the low number of individuals found (27-35), although the population seems fertile, we consider Amaranthus powellii as a casual alien species for India according to Pyšek et al. (2002). However, future monitoring will be carried out to check the possible naturalization of the species.

Amaranthus powellii S.Watson., Proc. Amer. Acad. Arts 10: 347. 1875 $\equiv$ Amaranthus chlorostachys var. powellii (S.Watson) Priszter, Agrártud. Egyet. Kert- Szölögazdaságtud. Karának Évk. 2: 144. $1953 \equiv$ Amaranthus hybridus subsp. powellii (S.Watson) Karlsson, Nord. J. Bot. 20: 519. $2000 \equiv$ Amaranthus hypochondriacus var. powellii (S.Watson) Pedersen, Monogr. Syst. Bot. Missouri Bot. Gard. 74: 1245. 1999 EAmaranthus retroflexus var. powellii (S.Watson) B.Boivin, Naturaliste Canad. 93(5): 641. 1966 - Lectotype (designated by Iamonico 2015: 157): USA, Arizona, "from Powell's Arizona seeds", 1874, Powell s.n. (US00106256!). Image of the lectotype available 
at http://n2t.net/ark:/65665/m3d80bd736-5d12-4c99a23a-1383db663680

Description: annual herb (therophyte), monoecious, $200-250 \mathrm{~cm}$ tall. Stem erect, reddish, glabrous (pubescent in the synflorescence region), ribbed, branched at the proximal half. Leaves simple, alternate, ovaterhombic $(10.5-14.5 \times 4.5-9.5 \mathrm{~cm})$, green, with entire margin, apex usually slightly emarginated, mucronate, base cuneate, glabrous, petioled (petiole pubescent, $12-14 \mathrm{~cm}$ long). Synflorescence terminal, panicle-like, few branched, the main florescence $28-30 \times 2-3 \mathrm{~cm}$, the paraclades $15-16 \times 1.5-2.0 \mathrm{~cm}$. Bracts lanceolatesubulate (7.0-8.5 mm long), 2.8-5.5 times longer than the perianth, green, glabrous, awned, with membranous borders narrowing to apex. Staminate flowers occurring throughout the synflorescences, with 5 unequal tepals, lanceolate-oblanceolate (2.5-3.4 mm long), mucronate; stamens (4-)5; anthers sagittate. Pistillate flowers occurring throughout the synflorescence, with 5 unequal tepals, lanceolate-linear (3.1-4.2 mm long), with acute and mucronate apex; gynoecium green, ovary 1-celled, 1 ovule, glabrous; stigmas $2-3$. Fruit brown, ovoid (1.3$1.8 \times 0.8-1.2 \mathrm{~mm}$ ), shorter than the perianth, dehiscent. Seed lenticular $(0.5 \times 0.6 \mathrm{~mm}$ in diameter $)$, black to reddish-brown.

Phenology: Flowering and fruiting times June-February. Habitat, distribution, and status of naturalization in India: Amaranthus powellii occurs in waste lands in three sites of Kasaragod District (Kerala State) at Chengala suburb [localities Naimarmoola $\left(54 \mathrm{~m}\right.$ a.s.l.) and $4^{\text {th }}$ Miles $(83 \mathrm{~m})]$ and Mulleria town $(173 \mathrm{~m})$. This species is currently considered as casual alien.

Chorology: native to North America and Mexico (see e.g., Mosyakin \& Robertson 2003). Some authors (e.g., Iamonico 2015a or Costea et al. 2001) considered Amaranthus powellii as native to North and South America.

Taxonomic notes: On the basis of the personal observation on hundreds of plants (by DI) and literature data, the Indian plants differ from the typical Amaranthus powellii by plant size and by the length of the bract of pistillate flowers. Concerning the height of plant, Indian plants of $A$. powellii are over than $2 \mathrm{~m}$ tall, while this species is usually up to $1.5 \mathrm{~m}$ high (see e.g., Mosyakin \& Robertson 2003, Iamonico 2015a). However, it is well known that this feature does not have a taxonomic value in Amaranthus and it depends from ecological factors, such as light, available nitrate in soil, trampling, etc. (see e.g., Iamonico 2010, Costea et al. 2004). On the other hand, the length of the bracts is a character commonly used to identify taxa in Amaranthus and especially in the $A$. hybridus group, where $A$. powellii belongs (see e.g., Iamonico 2015a). Individuals of $A$. powellii found in
India display bracts $7.0-8.5 \mathrm{~mm}$ long, whereas this species shows bracts up to $7 \mathrm{~mm}$ long (see e.g., Mosyakin \& Robertson 2003, Iamonico 2015a). The ratio bract/perianth (also a good taxonomic character in Amaranthus) is about $2.8-5.5$ in the Indian plants, whereas it is $2.0-3.7$ in A. powellii.

Specimina Visa Selecta: INDIA. Naimarmoola Kasaragod (north east), small population in the market road, 1251'52” N,7502'27”E, $54 \mathrm{~m}$ a.s.l, 10.X.2019, VS Anilkumar s.n. (CALI). 4th Mile (Kasaragod, South), scattered populations, $12^{\circ} 51^{\prime} 07^{\prime \prime} \mathrm{N}, 75^{\circ} 03^{\prime} 79^{\prime \prime} \mathrm{E}, 83 \mathrm{~m}$ a.s.l., 20.IX.2019, V S Anilkumar s.n. (TBGT). Mulleria (Kasaragod, North), along road sides and wastelands, $12^{\circ} 54^{\prime} 87^{\prime \prime} \mathrm{N}, 75^{\circ} 16^{\prime} 52^{\prime \prime} \mathrm{E}, 173 \mathrm{~m}$ a.s.l., 20.II.2020, VS Anilkumar s.n. (TBGT).

\section{List of Amaranthus species occurring in India}

At the current state of knowledge, no list of the species belonging to the genus Amaranthus has been published for the whole India since 1885, when Hooker (1885: 718-722), in the volume no. 4 of his Flora of British India, recognized 10 species plus three further "doubtful species". However, according to the current species concept in Amaranthus, only 8 species can be accepted (see Table 1 and literature therein cited).

Before Hooker (1885), a complete taxonomic treatment of Amaranthus for India was published by Roxburgh (1832) in the $3^{\text {rd }}$ volume of his Flora Indica where 18 species was recognized, but they currently refer to 6 species and 7 taxa (see Table 2 and and literature therein cited).

During the XX century, no taxonomic revision of $\mathrm{Am}$ aranthus was published for the India subcontinent, and we were able to trace just one taxonomic paper by Thakur (1967), who clarified the identity of the name "Amaranthus caturus Heyne" reaching to the conclusion that it refers to a hybrid between $A$. tricolor $\mathrm{L}$. and $A$. viridis $\mathrm{L}$.

Concerning XXI century, several new taxa were published by Das (2013), who described a new variety of A. tricolor L. (var. acutus Sabuhik Das), Das (2014, A. parganensis Sabuhik Das), Iamonico \& Das [2014, A. bengalensis Iamonico \& Sabuhik Das (as "bengalense")], Arya et al. (2019, A. saradhiana Arya et al.), and Sindhu et al. (2020, A. rajasekharii Sindhu et al.). Note that Das (2014) also reported from West Bengal $A$. dubius Mart. ex Thell. and A. hybridus L.

Currently, 19 taxa of Amaranthus (17 species) occur in India (Table 3), and this represents the first preliminary list of Indian amaranths published since 136 years. 
Table 1: List of recognized species by Hooker (1885: 718-722) as reported in the vol. 4 of Flora of British India [doubful species by Hooker (1885) are marked with an asterisk, ${ }^{*}$ ] and names currently accepted (if accepted names are different from the Linnaean ones, a reference is reported).

Tabela 1: Seznam vrst, ki jih je navedel Hooker (1885: 718-722) v četrtem delu Flora of British India [dvomljive vrste po Hooker (1885) so označene z zvezdico, ${ }^{*}$ ] in trenutno veljavna imena (če se veljavno ime razlikuje od Linnejevskih je neveden vir).

\begin{tabular}{ll}
\hline Recognized species by Hooker (1885) & Currently accepted names \\
\hline Amaranthus spinosus L. & Amaranthus spinosus L. \\
Amaranthus paniculatus L. & Amaranthus cruentus L. (Iamonico 2015: 55) \\
Amaranthus caudatus L. & Amaranthus caudatus L. \\
Amaranthus gangeticus L. & Nomen Incertae Sedis (Iamonico 2014a) \\
Amaranthus mangostanus L. & Amaranthus tricolor L. (Iamonico 2014b: 147) \\
Amaranthus caturus Heyne & Amaranthus $\times$ caturus Heyne ex Hook.f. (Thakur 1967) \\
Amaranthus viridis L. & Amaranthus viridis L. \\
Amaranthus blitum L. & Amaranthus blitum L. s.str. (Iamonico 2015a: 27) \\
Amaranthus polygamus L. & Amaranthus tricolor L. (Iamonico 2014b: 148) \\
Amaranthus tenuifolius Willd. & Amaranthus graecizans L. s.str. (Iamonico 2020b: 152) \\
Amaranthus atropurpureus Roxb.* & Amaranthus tricolor L. (Iamonico 2020c: 563). \\
Amaranthus campestris Willd.* & Amaranthus albus L. (Iamonico 2020b: 149) \\
“ Amaranthus rubricaulis Page”, nom. nud.* & Arts. 38.1 and 38.2 (Turland et al. 2018); see Iamonico (2016c: 89) \\
\hline
\end{tabular}

Table 2: List of recognized species by Roxburgh (1832: 601-611) as reported in the vol. 3 of Flora Indica and names currently accepted. Tabela 2: Seznam vrst, ki jih je navedel Roxburgh (1832: 601-611) v tretjem delu Flora Indica in trenutno veljavna imena.

\begin{tabular}{ll}
\hline Recognized species by Roxburgh (1832) & Accepted names \\
\hline Amaranthus tenuifolius Willd. & Amaranthus graecizans L. s.str. (Iamonico 2020b: 152) \\
Amaranthus polygonoides Willd. & Amaranthus polygonoides L. (Iamonico 2015a: 43) \\
Amaranthus polygamus Willd. & Amaranthus tricolor L. (Iamonico 2014b: 148) \\
Amaranthus tristis Willd. & Amaranthus tricolor L. (Iamonico 2014b: 144) \\
Amaranthus viridis Willd. & Amaranthus viridis L. (Iamonico 2015a: 22) \\
Amaranthus lividus Willd. & Amaranthus blitum L. s.str. (Iamonico 2015a: 27) \\
Amaranthus oleraceus Willd. & Amaranthus blitum L. var. oleraceus (L) Hook.f. (Iamonico 2015a: 29) \\
Amaranthus gangeticus Willd. & Nomen Incertae Sedis (Iamonico 2014a) \\
Amaranthus lanceolatus Roxb. & Amaranthus tricolor L. (Iamonico 2020c: 564). \\
Amaranthus atropurpureus Roxb. & Amaranthus tricolor L. (Iamonico 2020c: 563). \\
Amaranthus tricolor Willd. & Amaranthus tricolor L. \\
Amaranthus melancholicus Willd. & Amaranthus tricolor L. (Iamonico 2015a: 24) \\
Amaranthus fascicatus Roxb. & Amaranthus blitum L. s.str. (Iamonico, submitted ${ }^{6}$ ). \\
\hline
\end{tabular}

Table 3: Preliminary list of the species of Amaranthus occurring in India. Names are given in alphabetical order.

Tabela 3: Preliminarni seznam vrst rodu Amaranthus, ki se pojavljajo v Indiji. Imena so navedena po abecednem redu.

\begin{tabular}{ll}
\hline Amaranthus albus L. & Amaranthus polygonoides L. \\
Amaranthus bengalensis Iamonico \& Sabuhik Das & Amaranthus powellii S. Watson \\
Amaranthus blitum L. subsp. blitum var. blitum & Amaranthus rajasekharii S.Arya, V.S.A. Kumar, W.K.Vishnu \& \\
Amaranthus blitum L. subsp. blitum var. oleraceus (L.) Hook. f. & Iamonico \\
Amaranthus $\times$ caturus Heyne ex Hook. f. & Amaranthus saradhiana S.Arya, V.S.A. Kumar, W.K.Vishnu \& \\
Amaranthus cruentus L. & Rajesh Kumar \\
Amaranthus caudatus $\mathrm{L}$. & Amaranthus spinosus $\mathrm{L}$. \\
Amaranthus dubius Mart. ex Thell. & Amaranthus tricolor L. var. acutus Sabuhik Das \\
Amaranthus graecizans $\mathrm{L}$. subsp. graecizans & Amaranthus tricolor $\mathrm{L}$. var. tricolor \\
Amaranthus hybridus $\mathrm{L}$. & Amaranthus viridis $\mathrm{L}$. \\
Amaranthus parganensis Sabuhik Das & \\
\hline
\end{tabular}




\section{Acknowledgements}

Thanks are due to Directors and Curators of all the quoted herbaria for their support.

Sindhu Arya (D) https://orcid.org/0000-0002-2029-2456 Duilio lamonico (D) https://orcid.org/0000-0001-5491-7568 Venugopalan Nair Saradamma Anil Kumar (D) https://orcid. org/0000-0002-3809-2620

\section{References}

Arya, S., Anil Kumar, V.N.S., Vishnu, W.K. \& Kumar, T.R. 2019: Amaranthus saradhiana (Amaranthaceae) - a new species from southern Western Ghats of Kerala, India. Phytotaxa 403(3): 230-238. DOI: https://doi.org/10.11646/phytotaxa.403.3.7

Bayón, N.B. 2015: Revision taxonomica de las especies monoicas de Amaranthus (Amaranthaceae): Amaranthus subg. Amaranthus y Amaranthus subg. Albersia'. Annals of the Missouri Botanical Garden 101(2): 261-383. DOI: https://doi.org/10.3417/2010080

Costea, M., Sanders, A. \& Waines, G. 2001: Preliminary results towards a revision of the Amaranthus hybridus complex (Amaranthaceae). Sida 19: 931-974.

Costea, M., Weaver, S.E. \& Tardif, F.J. 2004: The biology of Canadian weeds. 130. Amaranthus retroflexus L., A. powellii S. Watson and $A$. hybridus L. Canadian Journal of Plant Science 84: 631-668. DOI: https://doi.org/10.4141/P02-183

Das, S. 2013: Infraspecific variability of Amaranthus tricolor (Amaranthaceae) in India with a new variety. Phytotaxa 88(2): 25-30. DOI: https://doi.org/10.11646/phytotaxa.88.2.2

Das, S. 2014: Amaranthus parganensis (Amaranthaceae), a New Species from West Bengal, India. Novon 23: 406-410. DOI: https://doi. org/10.3417/2012078

Das, S. 2016: Amaranthus: A Promising Crop of Future. Springer Nature, Singapore.

Das, S. \& Iamonico, D. 2014: Amaranthus bengalense (Amaranthaceae) a new species from India, with taxonomical notes on $A$. blitum aggregate. Phytotaxa 181(5):293-300. DOI: https://doi.org/10.11646/ phytotaxa.181.5.4

Hooker, J.D. 1885: Flora of British India 4. L. Reeve \& Co., London.

Iamonico, D. 2010: Biology, life-strategy and invasiveness of Amaranthus retroflexus L. (Amaranthaceae) in central Italy: preliminary remarks. Botanica Serbica 34(2): 137-145.

Iamonico, D. 2014a: Amarathus gangeticus (Amaranthaceae), a name incertae sedis. Phytotaxa 162(5): 299-300. DOI: http://dx.doi. org/10.11646/phytotaxa.162.5.2

Iamonico, D. 2014b: Lectotypification of Linnaean names in the genus Amaranthus L. (Amaranthaceae). Taxon 63(1): 146-150. DOI: http://dx.doi.org/10.12705/631.34

Iamonico, D. 2015a: Taxonomic revision of the genus Amaranthus (Amaranthaceae) in Italy. Phytotaxa 199(1): 1-84.

DOI: http://dx.doi.org/10.11646/phytotaxa.199.1.1
Iamonico, D. 2015b: Amaranthus powellii S.Watson. in Euro+Med Plantbase - the information resource for Euro-Mediterranean plant diversity. http://euromed.luomus.fi/euromed_map. php?taxon=449903\&size=medium (last accessed 17 August 2020).

Iamonico, D. 2016a: Nomenclature survey of the genus Amaranthus (Amaranthaceae). 3. Names linked to the Italian flora. Plant Biosystems 150(3): 519-531. DOI: http://dx.doi.org/10.1080/112635 04.2014 .987188

Iamonico, D. 2016b: Nomenclature survey of the genus Amaranthus (Amaranthaceae). 4. Detailed questions arising around the name Amaranthus gracilis. Botanica Serbica 40(1): 61-68.

Iamonico, D. 2016c: Nomenclature survey of the genus Amaranthus (Amaranthaceae). 5. Moquin-Tandon's names. Phytotaxa 273(2): 81-114. DOI: http://dx.doi.org/10.11646/phytotaxa.273.2.1

Iamonico, D. 2020a: Nomenclature survey of the genus Amaranthus (Amaranthaceae s.s.). 8. About Amaranthus polygonoides s.l. and $A$. anderssonii, two related taxa described from the tropical regions of America with notes on their taxonomy. Acta Botanica Mexicana 127: e1687. DOI: https://doi.org/10.21829/abm127.2020.1687

Iamonico, D. 2020b: A nomenclature survey of the genus Amaranthus (Amaranthaceae). 7. Wildenow's names. Willdenowia 50(1): 147-155. DOI: https://doi.org/10.3372/wi.50.50114

Iamonico, D. 2020: A nomenclatural survey of the genus Amaranthus (Amaranthaceae) 9: names published by Roxburgh. Taiwania 65(4): 559-566. DOI: https://doi.org/10.6165/tai.2020.65.559

Iamonico, D. \& Palmer, J. 2020: Nomenclature survey of the genus Amaranthus (Amaranthaceae). 6. Names linked to the Australian flora. Aust. J. Bot. 33: 169-173. DOI: https://doi.org/10.1071/SB18062

Mosyakin, S.L. \& Robertson, K.R. 1996: New infrageneric taxa and combination in Amaranthus (Amaranthaceae). Annales Botanici Fennici 33: 275-281.

Mosyakin, S.L. \& Robertson, K.R. 2003: Amaranthus L. In: Flora of North America Editorial Committee (eds.): Flora of North America North of Mexico (Magnoliophyta: Caryophyllidae 4. Oxford University Press, Oxford, pp. 410-435.

Palmer, J. 2009: A conspectus of the genus Amaranthus L. (Amaranthaceae) in Australia. Nuytsia 19: 107-128.

Park, Y-H., Park, S.-H. \& Yoo, K.-O. 2014: A newly naturalized species in Korea: Amaranthus powellii S. Watson (Amaranthaceae). Korean Journal of Plant Taxonomy 44(2): 132-135. DOI: https://doi.org/10.11110/kjpt.2014.44.2.132

POWO 2020-onward: Plants of the World Online. Amaranthus powellii S.Watson. Facilitated by the Royal Botanic Gardens, Kew. http://www.plantsoftheworldonline.org/taxon/urn:lsid:ipni. org:names:319617-2 (last accessed 17 August 2020).

Pyšek, P., Richardson, D.M., Rejmanek, M., Webster, G. L., Williamson, M. \& Kirschner, J. 2002: Alien plants in checklists and floras: towards better communication between taxonomists and ecologists. Taxon 53: 131-143. DOI: http://dx.doi.org/10.2307/4135498

Roxburgh, W. 1832: Flora Indica 3. W. Thacker \& Co. Calcutta, Serampore.

SANBI 2012: Biodiversity of life. Amaranthus powellii S.Watson. http://www.ville-ge.ch/musinfo/bd/cjb/africa/details. php?langue =an\&id=312 (last accessed 17 August 2020). 
Sindhu, A., Venugopalan Nair Saradamma, A.K., Walsan Kalarikkal, V. \& Iamonico, D. 2020: Amaranthus rajasekharii (Amaranthaceae), a new species from Kerala (SW-India). Phytotaxa 433(2): 153-160. DOI: https://doi.org/10.11646/phytotaxa.433.2.6

Thakur, V. 1967: The identity of Amaranthus caturus eyne. Kew Bulletin 21(1): 63-65.

Thiers, B. 2021 [continuously updated]: Index herbariorum, a global directory of public herbaria and associated staff. New York Botanical Garden's Virtual Herbarium. http://sweetgum.nybg.org/ih/ (last accessed 17 August 2020).

Turland, N.J., Wiersema, J.H., Barrie, F.R., Greuter, W., Hawksworth, D.L., Herendeen, P.S., Knapp, S., Kusber, W.-H., Li, D.-Z., Marhold, K., May, T.W., McNeill, J., Monro, A.M., Prado, J., Price, M.J. \& Smith, G.F. (eds.) 2018: International Code of Nomenclature for algae, fungi, and plants (Shenzhen Code). adopted by the Nineteenth International Botanical Congress, Shenzhen, China, July 2017. Regnum Vegetabile 159: 1-254.

Watson, S. 1875: Revision of the genus Ceanothus, and description of new plants, with a synopsis of the western Species of Silene. Proceedings of the American Academy of Arts and Sciences 10: 333-350. 